\title{
Public Attitudes toward Water Management Measures and Droughts: A Study in Southern Spain
}

\author{
Pilar Paneque ${ }^{1, *(\mathbb{D})}$, Regina Lafuente ${ }^{2}$ and Jesús Vargas ${ }^{3}$ \\ 1 Department of Geography, History and Philosophy, University Pablo de Olavide, Ctra. de Utrera 1, \\ 41013 Sevilla, Spain \\ 2 Institute for Advanced Social Studies, Spanish National Research Council (IESA-CSIC), C/Campo Santo de \\ los Mártires 7, 14004 Córdoba, Spain; rlafuente@iesa.csic.es \\ 3 Geography Laboratory, University Pablo de Olavide, Ctra. de Utrera 1, 41013 Sevilla, Spain; jvarmol@upo.es \\ * Correspondence: ppansal@upo.es; Tel.: +34-954-977-377
}

Received: 10 February 2018; Accepted: 21 March 2018; Published: 24 March 2018

check for updates

\begin{abstract}
In a context of climate change and more severe and frequent droughts, in order to achieve efficient and sustainable results, water-governance models must take into consideration different alternative management measures and the degree of social approval of each alternative. In this context, the present work analyzes public perceptions concerning water management- and climate change-related issues, especially in relation to the degree of social approval attained by six water management measures in Andalusia (southern Spain). These issues were included in the Ecobarómetro between 2004 and 2013, a period which was marked by the 2005-2008 drought. This analysis aims to increase our understanding of the state of public opinion in Andalusia on the basis that such knowledge is a necessary tool for political decision-making processes. The results and the conclusions have significant implications for water policy makers.
\end{abstract}

Keywords: drought; public attitudes; public perceptions; water management; water policy

\section{Introduction}

The transition towards new water management models, in a context of climate change, and therefore, of increased hydrological risk, is situated within a very complex setting with different spatial and chronological scales, and is beset by strong resistance to change and widespread uncertainty [1,2]. This complexity means there is a need to undertake institutional changes and thus that public participation must play a greater role in decision-making processes [3-5]. Institutional change will be harder to achieve in those territories where, as a consequence of path dependence, the inertia of traditional policies hampers the efficient implementation of more sustainable management models [6].

In Spain, for example, the supersession of traditional water policies faces substantial obstacles [7-9], despite the advances achieved since the enactment of the Water Framework Directive (WFD) in 2000 [10-13]. The consolidation of the productivist approach which has dominated water management in Spain for decades must be contextualized against a background of infrastructure-based interventionist policies. This traditional policy has fundamentally served agrarian interests and has generated substantial inertias [8], which hamper attempts to preserve the resource, preventive, and participative policies and the adaptation to the conditions of scarcity that characterize Mediterranean environments. The strength of hegemonic discourses linked to the agricultural sector (the main water consumer) is one of the main factors in Spanish water-related policy making: policy makers face droughts by enacting extraordinary normative measures, which is in line with the perspective of the so-called as "hydraulic age" or "hydraulic paradigm", and is still far from complying with the WFD objectives [14]. 
Concerning advances in Spanish water policy, especially with regard to participation in water policy, article 14 of the WFD encourages European Union member states to promote active participation, which must not only include organized agents (lobbies) but also the general public. This should contribute to solve conflict and build consensus and public awareness. However, the fact is that the incorporation of the general public into decision-making processes has been, at best, lukewarm.

This makes it doubly important to assess public awareness; this is a critical factor concerning the perception of resources and the perception of risks and the conditions under which decision making is carried out with regard to water policies. It is important to be aware of the degree of social approval enjoyed by different water management models, especially in areas where drought is frequent, as this affects public perceptions and beliefs [15-22]. Social support is a paramount factor for political action; from both a theoretical and an empirical perspective, management and policy decisions must reflect the preferences of the constituents [23].

Changes in the environmental behavior of the public have been abundantly debated in studies and surveys concerned with public environmental awareness [24-26]. Worldwide, there is the International Social Survey Program: Environment (1993-2010); in Europe, the Eurobarometer (1982-2014); in Spain, Ecología y Medio Ambiente (1996-2007); and in Andalusia, the Ecobarómetro (2001-2013). Studies that deal with public opinion concerning water resources are, in contrast, scarce, because few surveys include questions on water policies. In Europe, there is the Eurobarometer: Attitudes of Europeans towards water related issues (2009 and 2012); in Spain, Actitudes de los españoles ante la energía y el agua (2007); and, in Andalusia Opinión pública y recursos hídricos en Andalucía (2009).

In order to better understand the public's perceptions and attitudes regarding water policies, and to introduce this factor into the debates concerning water policies in Andalusia, this work analyses public opinions concerning such issues as climate change, the quantity and quality of water resources, and the uses that different sectors make of water. The degree of public support enjoyed by different water management alternatives in the period 2004-2013 was also analyzed, using data from the Ecobarómetro de Andalucía (EBA).

The present work focuses on the Guadalquivir River Basin (GRB), which is currently under the management of the central government, and to those river basins currently under the management of the regional government: Cuencas Mediterráneas Andaluzas (DHCMA), Guadalete-Barbate (DHGB) and Tinto-Odiel-Piedras (DHTOP). For the sake of brevity, we use "Andalusia" and "Andalusians", in order to refer to the territory comprised by the four basins and their population. This region in southern Spain, with a total area of $87,597 \mathrm{~km}^{2}(17.3 \%$ of the national territory), is affected by alternating dry and humid cycles. During the latest significant drought episodes (1941-1945, 1979-1983, 1990-1995, and 2005-2008) precipitation dropped by between $23 \%$ and $30 \%$ in the different basins into which the region is divided

Nowadays, as a result of the persistence of the traditional water policy in Spain and specially in Andalusia, that has favored the increase of water supply mainly in favor of agriculture (agriculture use reaches $81.2 \%$ of water use in Andalusia, compared to $15 \%$ for domestic use and 3\% for industrial use), all the Andalusian river basins are subject to high levels of quantitative and qualitative water stress. Regarding qualitative issues, all the river basin present an important percentage of water bodies which do not reach the "good status" which is required for 2015 for all water bodies, according to the WFD. According to according to the Andalusian's hydrological river basis plans Cuencas Mediterráneas Andaluzas (DHCMA) presents a $48 \%$ of water bodies (surface and groundwater bodies) which do not reach the "good status", Guadalete-Barbate (DHGB) presents a 55\%, Guadalquivir presents a 38\% and Tinto-Odiel-Piedras presents a 52\%. In sum for the whole Andalusian region, the $43 \%$ (418 of 959) of water bodies are in a "bad status". Furthermore, due to the intensive use of resources and according also to the Andalusian's river basin plans all the four river basin present a high level of water stress according to WEI+ index (Water Exploitation Index): Cuencas Mediterráneas Andaluzas (50\%), Guadalete-Barbate (57\%), Tinto-Odiel-Piedras (47\%), and Guadalquivir (53\%). This strong pressure on water resources, both on its quantitative and on its qualitative status in all Andalusian river basin 
districts make them much more vulnerable when a period of drought appears. These periods have in common the intensity of the debate on drought and water management, and a context of relevant institutional changes, which clearly shows the position of the different stakeholders involved [14].

\section{Methodology}

\subsection{Database: Ecobarómetro de Andalucía (EBA)}

The source used to carry out the statistical analysis was the EBA, a survey about environmental attitudes carried out annually between 2001 and 2013 (with the exception of 2012) by the Andalusian Environment Ministry and the Institute for Advanced Social Studies (IESA-CSIC). The EBA is designed on the basis of the concept of environmental awareness, which is defined as "the set of perceptions, opinions and knowledge of the public concerning the environment, as well as their attitude, behaviour and willingness to take action (individually and collectively) towards the mitigation of environmental problems" [27] (p. 8). From an analytical perspective, the concept of environmental awareness embraces several dimensions, including the emotional (concerns, beliefs and values), the cognitive (information and knowledge) and the active (individual and collective action) [26]. The combination of these three dimensions reflect public preferences concerning environmental policies, including those aimed at increasing the availability of hydrological resources and those aimed at rationalizing or even limiting its consumption [27].

This analysis focuses on the period 2004-2013, as during this period the survey incorporated questions concerning water management. In order to adjust the data to the temporal dimension of the study, the results for the years under consideration have been conflated into a single dataset, comprising 19,627 responses. Although the design of the EBA sample guarantees the representativeness of results at the provincial and the annual levels (levels are stratified by subsampling in clusters and the selection of final units by random routes, age and gender), in this case the sample has been subject to post-stratification [28], which takes into consideration the distribution of the population by age and gender in each basin and year. The level of expected absolute error of the results of the survey, for the frequency of each variable, is $\pm 1.9 \%$, with a confidence level of $95 \%$.

\subsection{Water Management Measures}

The indicator used to measure public support for the different management measures is calculated on the basis of responses to the following question: "Among the following water management-related measures, which do you consider the most adequate for water management in Andalusia?" Each year, respondents are provided with a list of 10 measures, from which they must choose. The analysis has taken into consideration six water management-related measures included in the EBA which meet two basic criteria: they are present in all annual surveys and they have scored a minimum of $5 \%$ of support throughout the series: (1) "Building more reservoirs"; (2) "Transferring water from other regions"; (3) "Using sea water"; (4) "Improving irrigation in order to reduce consumption"; (5) "Reducing amount of irrigation"; and (6) "Reducing household consumption". The measures which did not meet both criteria are: increasing the price of water (2004-2013), decreasing construction activities in areas where water is scarce (2004-2008), digging more wells (2004-2011), reusing residual water (2009-2013), improving distribution networks and controlling the contamination of rivers and underground water bodies (2013).

\subsection{Contextual Variables}

Support for any given measure is dependent on a set of shared beliefs, values, and personal characteristics. The questionnaire is broad in scope, and this allows for the sociodemographic and ideological profiling of the interviewees, as well as the evaluation of the degree of public confidence in the institutions to be measured, etc. In this work, more general factors have also been taken into 
consideration, such as public concerns about the quality and quantity of water available and the degree of understanding of how water is used by different social and economic sectors.

1. Concern over climate change: the measures public concern about climate change, and compares it with that about other global environmental threats. The respondents are presented with a list of problems, for them to select the two that concerns them the most. The list of problems at the global scale comprises: (1) Exhaustion of natural resources; (2) Climate change; (3) The extinction of plant and animal species; (4) Advancing erosion and desertification; (5) Destruction of the ozone layer; (6) Contamination of the oceans. The indicator of climate change used is the sum of responses that select climate change as the most or second most important problem globally.

2. Concern about drought: in the regional level, respondents are presented with another set of problems that concern Andalusia: (1) Soil erosion and desertification; (2) Wildfires; (3) Pollution of beaches and oceans; (4) Pollution of rivers; (5) Water scarcity; (6) The extinction of plant and animal species; (7) Air pollution; (8) The disappearance of natural landscapes. In this work, we highlight the percentage of respondents who have pointed to water scarcity as the most or second most important environmental problem for Andalusia.

3. Concern about water quality: the methodology used to measure this indicator is similar to that adopted in the previous cases. Respondents are presented with a list of problems for them to select the two which they are more concerned about in the local scale: (1) The deterioration of the urban landscape; (2) The quality of tap water; (3) Noise pollution; (4) Garbage and solid urban waste; (5) Air pollution; (6) Street cleanliness; (7) Shortage of parks and public gardens.

4. Level of environmental information: the indicator is calculated on the basis of the answers to the question: "To what extent do you consider yourself well informed about environmental issues?" That is, the indicator reflects the respondent's perception of their own level of knowledge and, therefore, can also be considered a proxy of the personal interest in environmental matters. In this work we use the percentage of respondents that consider themselves "well" or "very well" informed about environmental matters.

5. Knowledge of water allocation criteria: in this work we use the percentage of respondents who have declared the following statement to be false: "More water is consumed in the domestic sphere than in the agricultural sector."

\section{Results}

Public preferences concerning water management policies are situated within a broader framework of attitudes and opinions regarding the environment and climate change, as well as of more specific issues, such as the quality and quantity of water sources and the distribution of water.

The diachronic nature of the EBA reflects the changes undergone by public opinion between 2004 and 2013, and allows us to measure the impact of the drought suffered by Spain between 2005 and 2008. The decade under analysis was also especially significant concerning the management and planning of hydrological resources in Andalusia. These years witnessed a severe drought (2004-2008), which led to the mobilization of agricultural associations and urban water-supply restrictions [14]. The situation drove the central and regional administration to adopt urgent measures that differed from those preventive strategies that should be used in the management of hydrological risks [13], namely:

1. The passing in July 2005 of a drought protocol in the Guadalquivir basin, which replaced the Plan Especial de Actuación en Situación de Alerta y Sequía (Special Plan of Action in Alert and Drought Conditions) (PES); this, according to national legislation, should have been published as of 2003.

2. The publication, on a national level, of several decrees Royal Decrees Law (RDL) (RDL 10/2005, RDL 9/2006, RDL 9/2007, RDL 3/2008, RDL 8/2008, and RDL 14/2009) that justified the undertaking of works considered to be in the general public interest, especially concerning the construction of infrastructures, the use of underground water sources, the improvement of irrigation systems, the regulation of transactions involving water rights, the setting up of 
lines of credit, and the justification of the temporary modification of the environmental criteria established in hydrological planning documents.

3. The publication of a regional decree which affected the province of Malaga and the Mediterranean coastline (Decreto 240/2005).

In addition to these actions, after the aforementioned transposition of the WFD into Spanish legislation in 2003 and the publication of program AGUA (Actuaciones para la Gestión y la Utilización del Agua-Water Management and Use Actions) in 2004, the period 2004-2013 was characterized by the passing of the Ley de Aguas de Andalucía (Andalusian Water Act) (Ley 9/2010); the publication of the hydrological plans of the DHCMA (Cuencas Mediterráneas Andaluzas River Basin District), DHGB (Guadalete-Barbate River Basin District), and DHTOP (Tinto-Odiel-Piedras River Basin District) in 2010; the DHG (Guadalquivir River Basin District) in 2013; the belated PES in the Guadalquivir in 2007, and the intraregional basins, in 2008.

This intense planning and legislative activity was in addition to relevant administrative novelties which handed, albeit temporarily, water management to the regional government exclusively (RD 2130/2004 and RD 1560/2005 for the internal basins and RD 1666/2008 for the Guadalquivir basin). In order to administer this, the regional government created the Agencia Andaluza del Agua (Andalusian Water Agency) in 2005.

The 2005-2008 episode of drought divides the period under consideration into three stages: pre-drought (2004), drought (2005-2008), and post-drought (2009-2013). We analyze to what extent changes in public preferences concerning water management policies throughout the period can be attributed to the effects of drought. Finally, we examine the relationship between the contextual indicators and the water management measures investigated in the previous sections.

\subsection{Perception of Climate Change and of the Quality, Quantity, and Distribution of Water Resources}

Public perceptions of environmental degradation vary widely from region to region. The EBA confirms that people tend to consider environmental problems as more acute if they occur in places far away or over long periods of time. Generally, environmental problems are presented as occurring on different scales, according to their territorial scope and social repercussions. The EBA categorizes public environmental concern using local, regional, and global scales. Figure 1 presents a selection of environmental concerns which, in our opinion, have a direct bearing on water management: concern over climate change, concern over water scarcity at the regional level, and concern over the quality of the public water supply at the local level.

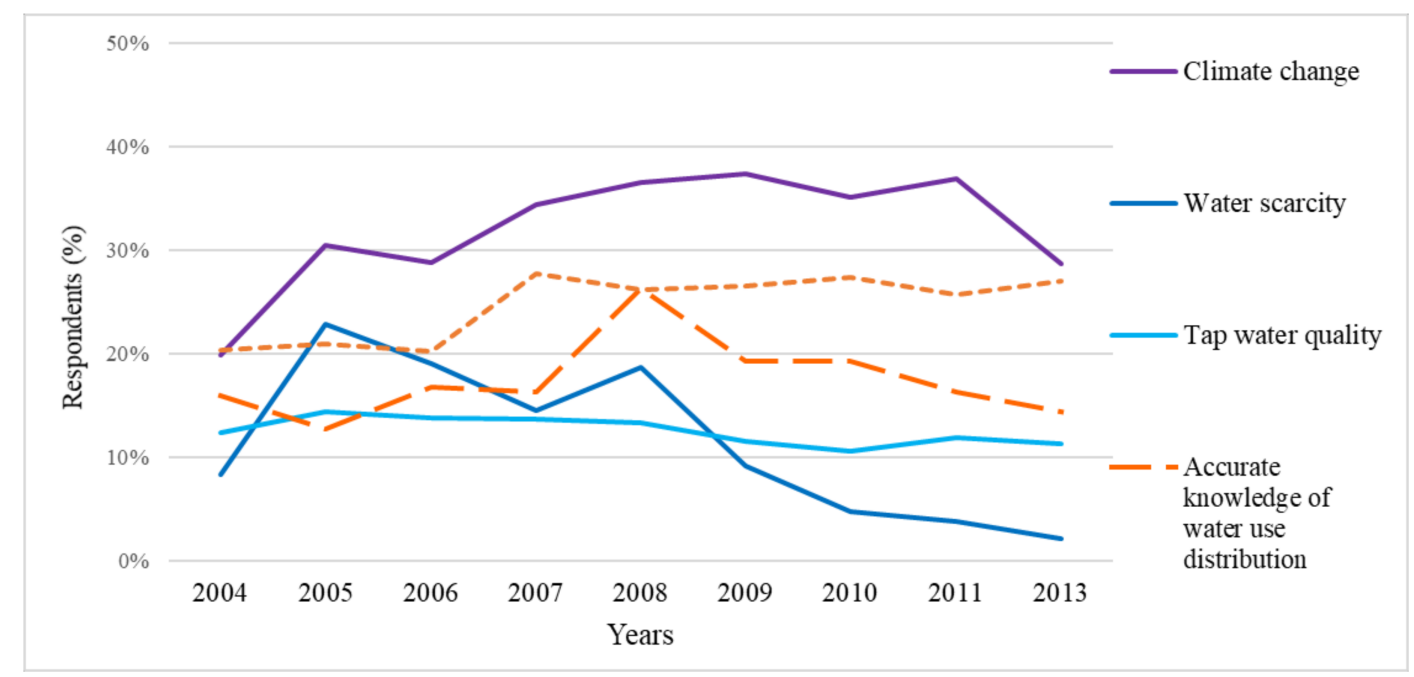

Figure 1. Contextual variables in Andalusia, 2004-2013 (\%). Source: Authors' own after Ecobarómetro de Andalucía (EBA) 2001-2013 (IESA-CSIC). 
At a global level, concern about climate change has increased in a sustained manner: whereas in $2004,19.9 \%$ of the population believed that this problem was the most concerning issue on a planetary scale, by 2005 the percentage had soared to $30.4 \%$, and by 2006 it was the second most concerning matter, behind the destruction of the ozone layer. From 2007 onwards, this problem has consistently featured at the top of the list of concerns (Figure 1).

On a regional scale, concerns over the scarcity of water in Andalusia vary substantially from year to year, largely depending on precipitation levels; Andalusia has a Mediterranean climate, and as such precipitation regimes are irregular and unpredictable (Figure 1). In 2004, 8.3\% of respondents singled out this problem as the most concerning at regional level, whereas during the period of drought in 2005 the percentage increased to $22.8 \%$. Once the drought was over, in 2009, public concern over this issue dropped to $9.1 \%$. From that year onwards, water scarcity has remained at the bottom of the list of concerns presented by the survey. As we shall see shortly, the fact that concern over water scarcity is so closely tied to the level of rainfall will have a direct bearing on the support given to different water management policies.

Finally, on a local scale, tap water quality is mentioned by approximately $12 \%$ of respondents, and no significant fluctuations were detected from year to year (Figure 1). However, as suggested in the Ecobarómetro's annual reports, concerns about water quality are more acute in towns with a population under 5000, where in some years this issue has been selected by as many $30 \%$ of respondents.

One of the factors which has a direct bearing on public preferences regarding water management policies is the information that the public has concerning the volume of water consumed by different economic sectors [29]. In the period under consideration, $81.3 \%$ of water used went to agriculture, $15.1 \%$ to households, $2 \%$ to industrial uses, and $1.6 \%$ to other uses [30-33]. The data collected by the EBA, however, indicates that most people think households consumed the most water. As illustrated in Figure 1, the percentage of those who correctly rejected the statement "most water is consumed by households" oscillates between $12.7 \%$ (2005) and $26.1 \%$ (2008). The level of unsubstantiated belief concerning water distribution among sectors can be compared to the self-declared lack of knowledge concerning environmental problems. Most of the respondents admitted to having little or no knowledge concerning environmental issues. Roughly one in four claimed to be fairly or very well informed, but the proportion of those who stated they were well informed increased by approximately $7 \%$ between 2004 and 2013. Paradoxically, although the respondents were increasingly confident about the level of environmental awareness that they possessed, the percentage of correct answers concerning the distribution of water use decreased over time.

\subsection{Public Support for Water Management Measures}

Concerning the support provided by Andalusians for the six water management measures under analysis during the decade 2004-2013, the first thing that stands out is the considerable decrease in support for the measure "Building more reservoirs", even if it still occupies the third position in the last survey (see Figure 2).

In 2004, this measure garnered the most support — nearly half the population (45\%). From 2006 onwards, the proportion of people supporting the construction of these infrastructures drops to $14 \%$ in 2013. It must be taken into consideration that the main water-related concern in Andalusia is perceived scarcity, especially in drought years [27]; therefore, after the initial alarm that followed the beginning of the drought in 2004 had died away, water-related concerns receded somewhat, and with this the support for the construction of major infrastructures.

This trend runs parallel to fatigue for the traditional hydraulic paradigm, and is especially connected to economic and technical features, which make it very difficult to further regulate the flow of Andalusian rivers, as well as to trends of a global nature [9]. Despite this, the administration has continued with the construction and planning of new reservoirs in Andalusia, as reflected in the hydrological plans (i.e., Arenoso, Casasola, La Breña II, Los Melonares, Siles, Alcolea, Coronada, Guadarranque, Gibralmedina, etc.). 


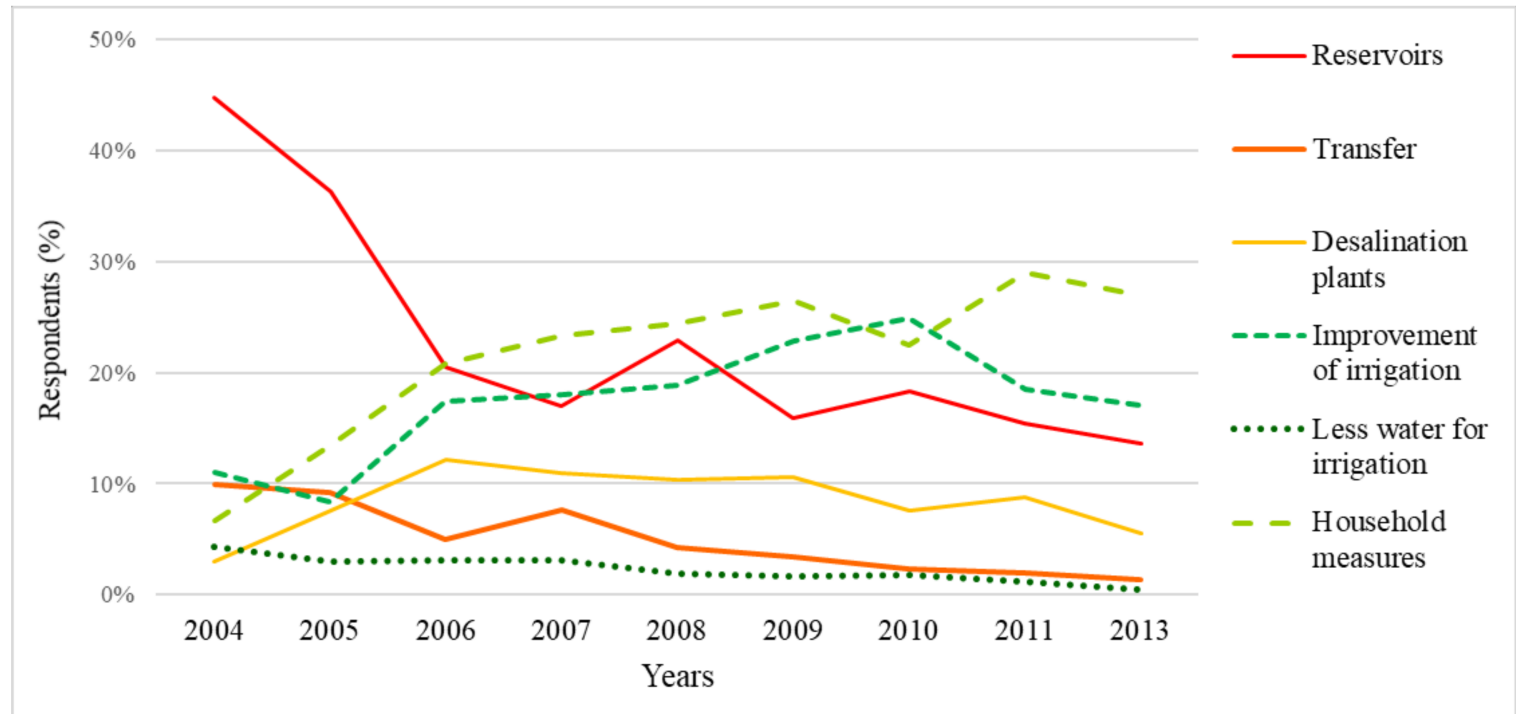

Figure 2. Support for water management measures in Andalusia 2004-2013 (\%). Source: Authors' own after Ecobarómetro de Andalucia (EBA) 2004-2013.

While support for the construction of new reservoirs drops, support for measures aimed at the promotion of a more efficient use of water, such as "improving irrigation in order to reduce consumption" and "reducing household consumption", has grown, from $11 \%$ to $17 \%$ and from $6.7 \%$ to $27 \%$, respectively. The inflexion point in these changes was 2006 , following two years of drought (which served to highlight the need for efficiency). It is of note, however, that despite the constant increase in agrarian demands in Andalusia [34], the improvement of irrigation systems, which in 2010 was backed by $25 \%$ of the population, has of late descended to 2006 levels (17\%). This is related to the strong degree of social legitimacy enjoyed by irrigation in Andalusia [35], the effects of agricultural discourses in the media [14], and the fact that the way consumption is distributed according to sector is poorly understood. For instance, the support for measures aimed at reducing household consumption is related to the widespread perception that most water resources in Andalusia are consumed at household level, as previously noted: only $17 \%$ of the population deny this statement [27].

The less popular measures in the series, and also the most stable, are "transferring water from other regions" (from 10\% in 2004 to 1.4\% in 2013), "using sea water" (from 3\% to 5.5\%), and "reducing water available to irrigation" (from $4.3 \%$ to $0.4 \%$ ). Of note is the less than enthusiastic support garnered in the last interview by "reducing water available to irrigation", which also presents the most homogenous behavior of the whole series, stressing once more the strength of the social legitimacy of agriculturalists, the widespread unawareness concerning the way in which consumption is distributed, and, in short, the difficulties of tackling the real problem of water consumption in Andalusia.

\subsection{Drought and Public Opinion}

This section presents a descriptive analysis of the evolution of public opinion in the three periods under consideration: pre-drought (2004), drought (2005-2008), and post-drought (2009-2013). This exercise has a two-fold purpose. First, to test whether perceptions about water-related environmental problems are affected by drought, and second if these potential changes in perceptions are sustained over time.

The post-stratification applied to the Ecobarómetro's data (see methodology) allows us to divide the database into the three periods, taking into consideration that only $10.4 \%$ of the responses correspond to $2004,43.7 \%$ to the period $2005-2008$, and $45.9 \%$ to the period $2009-2013$. In order to ascertain whether there are significant changes in the opinion of respondents throughout the period under examination, a chi-square proportion test was calculated for each variable (Table 1). 
Table 1. Comparison of results from the three periods. Source: Authors' own after EBA 2001-2013 (IESA-CSIC).

\begin{tabular}{|c|c|c|c|c|}
\hline Public $\mathrm{O}_{\mathrm{F}}$ & $\begin{array}{l}\text { nion and Drought: Comparasion Column } \\
\text { Proportions (z-tests) }\end{array}$ & $\begin{array}{l}\text { Pre-Drought } \\
2004 \\
\text { (A) }\end{array}$ & $\begin{array}{l}\text { Drought } \\
\text { 2005-2008 } \\
\text { (B) }\end{array}$ & $\begin{array}{l}\text { Post-Drought } \\
\text { 2009-2013 } \\
\text { (C) }\end{array}$ \\
\hline \multirow{5}{*}{$\begin{array}{l}\text { Contextual } \\
\text { variables }\end{array}$} & Climate change & $19.9 \%$ & $\begin{array}{l}32.6 \% \\
\mathrm{~A}\end{array}$ & $\begin{array}{c}34.5 \% \\
\mathrm{AB}\end{array}$ \\
\hline & Water scarcity & $\begin{array}{c}8.3 \% \\
\mathrm{C}\end{array}$ & $\begin{array}{l}18.7 \% \\
\mathrm{AC}\end{array}$ & $4.9 \%$ \\
\hline & Tap water quality & $12.3 \%$ & $\begin{array}{c}13.8 \% \\
\mathrm{C}\end{array}$ & $11.3 \%$ \\
\hline & Fairly or very well informed & $20.3 \%$ & $\begin{array}{c}23.8 \% \\
\mathrm{~A}\end{array}$ & $\begin{array}{l}26.7 \% \\
\mathrm{AB}\end{array}$ \\
\hline & Accurate knowledge of water use distribution & $15.9 \%$ & $18.1 \%$ & $17.3 \%$ \\
\hline \multirow{6}{*}{$\begin{array}{c}\text { Water } \\
\text { management } \\
\text { policies }\end{array}$} & Reservoirs & $\begin{array}{c}44.8 \% \\
\mathrm{BC}\end{array}$ & $\begin{array}{l}24.1 \% \\
\mathrm{C}\end{array}$ & $15.8 \%$ \\
\hline & Transfers & $\begin{array}{l}9.9 \% \\
\mathrm{BC}\end{array}$ & $\begin{array}{c}6.5 \% \\
\mathrm{C}\end{array}$ & $2.3 \%$ \\
\hline & Desalinisation plants & $3.0 \%$ & $\begin{array}{c}10.3 \% \\
\mathrm{AC}\end{array}$ & $\begin{array}{c}8.1 \% \\
\mathrm{~A}\end{array}$ \\
\hline & Increased efficiency in irrigation & $11.0 \%$ & $\begin{array}{l}15.7 \% \\
\mathrm{~A}\end{array}$ & $\begin{array}{l}20.8 \% \\
\mathrm{AB}\end{array}$ \\
\hline & Increased efficiency in the domestic sphere & $6.7 \%$ & $\begin{array}{c}20.5 \% \\
\mathrm{~A}\end{array}$ & $\begin{array}{c}26.3 \% \\
\mathrm{AB}\end{array}$ \\
\hline & Less water for irrigation & $\begin{array}{l}4.3 \% \\
\mathrm{BC}\end{array}$ & $\begin{array}{c}2.8 \% \\
\mathrm{C}\end{array}$ & $1.3 \%$ \\
\hline
\end{tabular}

Concern about climate change increased steadily throughout the period under consideration (see Figure 1), and this increase was particularly sharp from 2005 onwards. While from 2004 to the drought period this indicator rises from 19.9 to $32.6 \%$ of responses, the increase is much less pronounced between the second and third period, when the indicator reaches $34.5 \%$ of responses. In contrast, with regard to concerns about water scarcity, the highest values correspond to the drought period $(18.7 \%)$, whereas in the previous period this concern was selected by only $8.3 \%$ of respondents, and by a mere $4.9 \%$ of respondents in the post-drought period. Regarding concerns about the quality of tap water, the perceptions are pretty much the same throughout the period under examination. Regardless of the substantial impact that the 2005-drought had for southern Spain, the answers indicate that this only concerned one out of every four Andalusians. However, because of the way indicators are designed (see methodology), environmental concerns are compared with other concerns, and it has to be taken into account that concerns about forest fires amounted to over $50 \%$ of responses for every single year. In 2005, however, water scarcity was not only among the most pressing concerns with regard to environmental conditions, but was spontaneously singled out as one of the three main problems besetting Andalusia (generally, these problems are related to unemployment and the economy). Overall, all environmental problems combined amounted to approximately $5 \%$ of responses, but in 2005 water scarcity was mentioned by $18.4 \%$ of respondents, and in 2006 by $7.4 \%$.

According to the results illustrated in Table 1, public interest on environmental matters has progressively increased over time, but knowledge of water allocation criteria has remained stable: in 2004, only $15.9 \%$ of respondents knew that most water is not consumed in the domestic sphere, a percentage that only increased slightly, to $18.1 \%$ in $2005-2008$, and then decreased to $17.3 \%$ in $2009-2013$.

As summarized in Table 1, during the period of drought (2005-2008), public preferences concerning water management policies underwent significant changes and, what is more remarkable, 
is that these changes persisted during the post-drought period (2009-2013). The construction of reservoirs and the transfer of water lost support during the drought period and continued to decrease significantly during the post-drought period. The $44.8 \%$ of the respondents that showed preference for the construction of reservoirs in 2004, dropped to $24.1 \%$ during the 2005-2008 drought, and then it fell even further to $15.8 \%$ in the post-drought period. Water transfer, which was less popular than reservoirs to start, presents the same trend: from $9.9 \%$ of support in 2004 to $6.5 \%$ during the drought, and $2.3 \%$ during the post-drought period.

Conversely, public support for measures that aimed to increase efficiency in both domestic and agricultural water use increased significantly both during and after the period of drought. Before the drought, saving water in the domestic sphere and in agriculture were the preferred policy options for only $6.7 \%$ and $11 \%$ of respondents, respectively. These percentages increased during the drought period. Those respondents who supported saving water in the domestic sphere (20.5\%) where more numerous than those who supported more efficient irrigation systems (15.7\%). After the drought, support for both measures continued increasing ( $26.3 \%$ and $20.8 \%$, respectively).

Public support for the construction of desalinization plants increased during the period of drought (from 3\% to $10.3 \%$ ) but, uniquely, this support ceased to grow in the post-drought period (8.1\%).

Finally, although the possibility of decreasing the quantity of water available to irrigation has been met with little public support throughout the series, it was somewhat more popular before the drought $(4.3 \%)$ than during the drought $(2.8 \%)$ and in the post-drought period $(1.3 \%)$. These results suggest that the drought period 2005-2008 affected mainly public perceptions concerning the quality of water available at regional level. Public concern about climate change has steadily increased throughout the period under consideration, with the sharpest increase taking place during drought period. At any rate, although during the drought period public debate about water availability intensified significantly, with the help of growing media coverage, public knowledge about water allocation criteria did not improve substantially. The following section examines to what extent this lack of knowledge, and other contextual variables, is associated with the increased support for measures related to a more efficient use of water in both the domestic and the agricultural spheres.

\subsection{Relationship between Environmental Beliefs and Support for Water Management Policies during the Three Periods under Consideration}

In the year prior to the drought (2004), at a time when concerns over water scarcity and the quality of tap water were low (see Table 1), respondents who expressed the greatest concern over these issues were less supportive of the construction of reservoirs than others (see Figure 3); this was at a time when the construction of these infrastructures still enjoyed a substantial level of social legitimacy (see Table 1). In fact, while for $45 \%$ of respondents building reservoirs is the best water-management option, this measure only garners the support of $33.1 \%$ of the respondents who had previously expressed some concern about water scarcity.

Those respondents who expressed the greatest concern over climate change, emphasized the need to improve irrigation (11.6\%) and those who expressed the greatest concern for water scarcity more frequently mentioned the need to make inter-regional transfers $(17.3 \%)$.

During this period, a high level of environmental awareness and an accurate knowledge of water distribution did not have a relevant impact on preferences concerning water management policies.

The most important change in public preferences concerning water management policies during the period of drought was the significant decrease in support for the construction of water reservoirs; in contrast, support for measures based on increased efficiency grew (see Table 1). In this regard, those who expressed the most concern over climate change were especially supportive of measures that aimed to increase efficiency in the domestic environment $(22.1 \%)$, whereas those who expressed the greatest concern over water quality tended to demand an increase in the efficiency of irrigation systems (18.4\%). Public concern over water scarcity increased during this period (see Table 1), and 
those who expressed this concern were less supportive of increasing efficiency in irrigation $(12.8 \%)$ than the rest of the respondents $(16.4 \%)$.

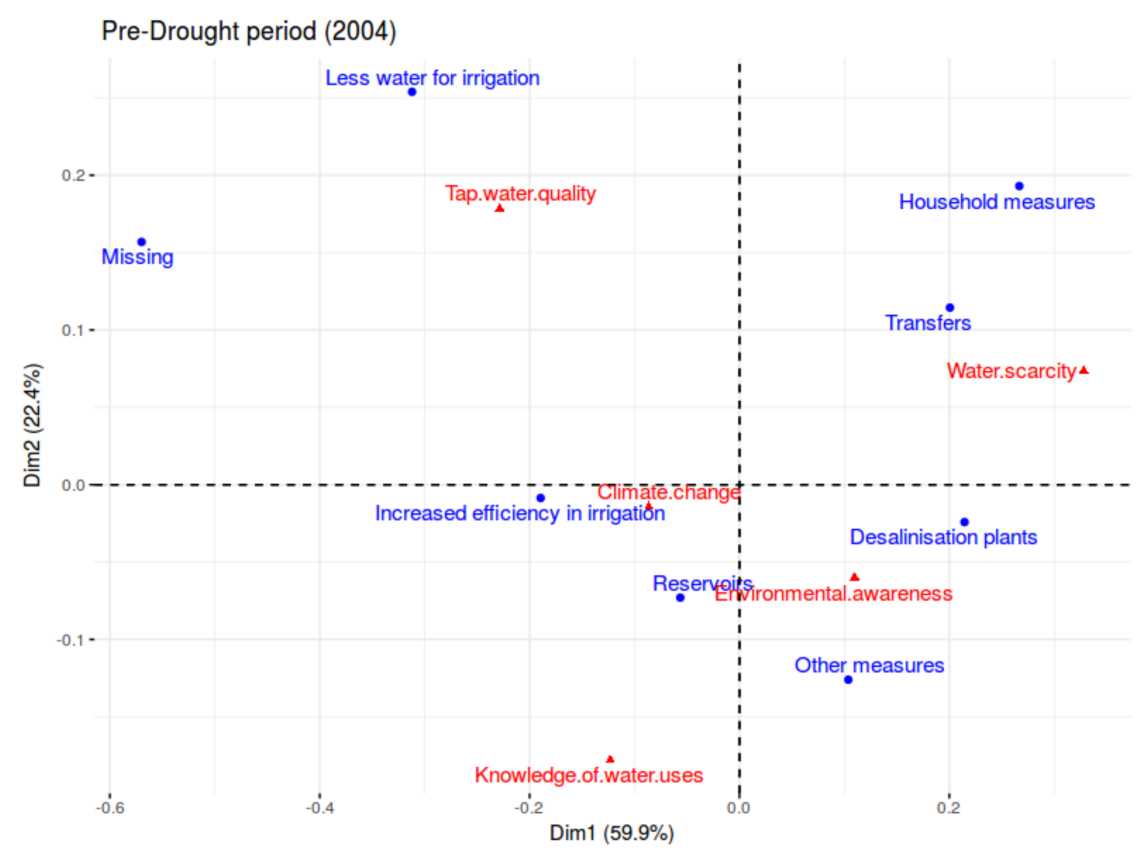

Figure 3. Correspondence analysis: context variables and public preferences concerning water management policies in the pre-drought period (2004). Source: Authors' own after EBA 2004-2013 (IESA-CSIC).

Environmental awareness and an accurate knowledge of water distribution among different sectors play a crucial role in shaping respondents' preferences concerning water management policies during the period of drought. Respondents with a higher level of environmental awareness and knowledge of water distribution believed that improving irrigation (selected by $19 \%$ ) is more important than optimizing domestic consumption, whereas the rest of the respondents tended to focus on the domestic environment (around 22\%). However, respondents with a higher level of environmental awareness preferred household measures (17\%) than those that have an accurate knowledge of water allocation (11.7\%) (Dimension 1 in Figure 4). These groups of respondents also expressed greater support for the construction of desalinization plants than other respondents (Dimension 2 in Figure 4). It is true that support for desalinators seems not to be related to greater degrees of environmental awareness, for this measure also implies the generation of more resources, rather than a more rational consumption of what resources are available, but it has to be taken into account that the national framework water policy at the time (the aforementioned Programa AGUA)—which was considered a great step forward with regard to traditional policies (the construction of great reservoirs and transfers) - made a substantial bid for the construction of desalination plants. In addition, although reducing the quantity of water available to irrigation was a rather unpopular measure, those who knew that most water is used by the agricultural sector were somewhat more supportive of this measure $(3.9 \%)$ than the rest of the respondents (2.1\%) (Dimension 1 Figure 4$)$.

After the drought (2009-2013), public support for measures that aimed to increase efficiency in domestic and agricultural contexts was consolidated (see Table 1). Concern over climate change increased during this period (see Table 1), and the association between climate change and measures aimed at improving efficiency at the domestic level continued (28.8\%). However, it should be noted that those who continued expressing their concern over water scarcity after the drought (barely $5 \%$ of respondents) were more supportive of the construction of reservoirs and water transfers: $22 \%$ and $4 \%$ respectively, compared to $15.5 \%$ and $2.2 \%$ overall (Figure 5). 


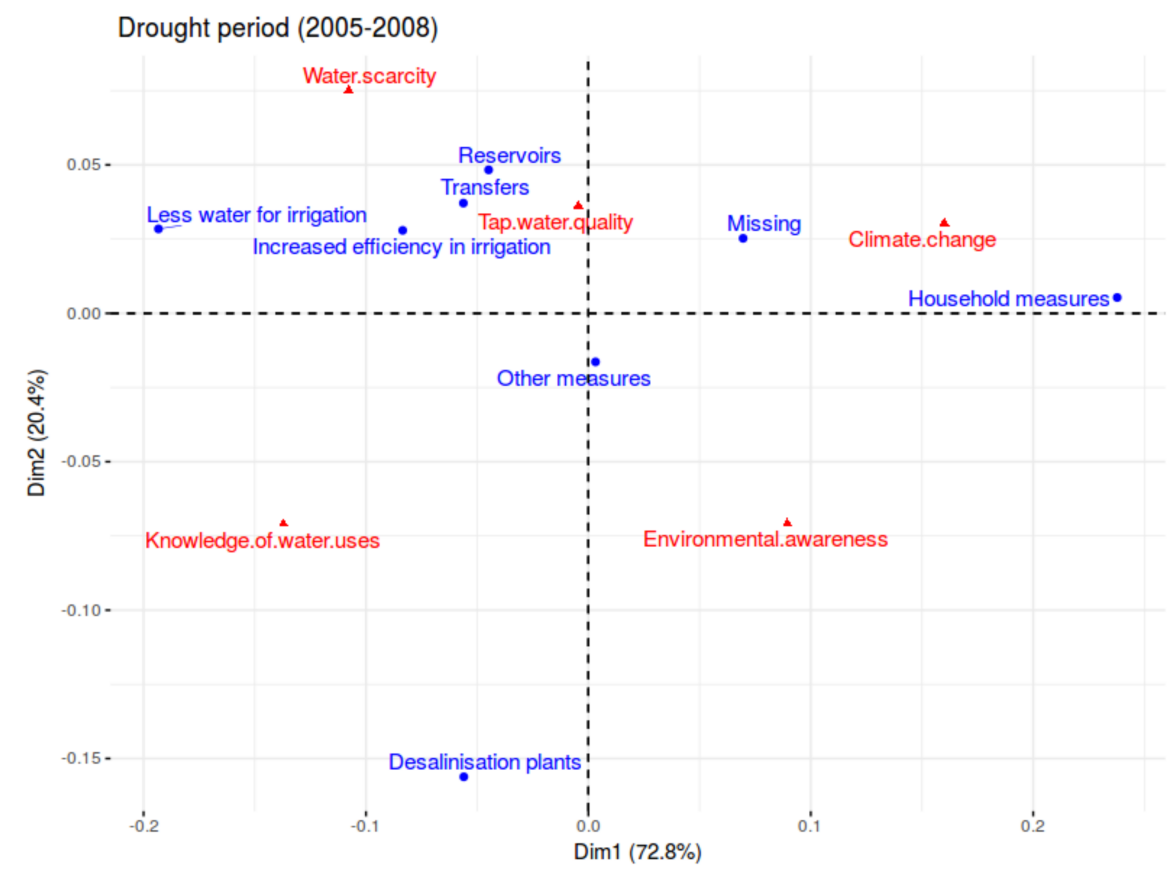

Figure 4. Correspondence analysis: context variables and public preferences concerning water management policies in the period of drought (2005-2008). Source: Authors' own after EBA 2004-2013 (IESA-CSIC).

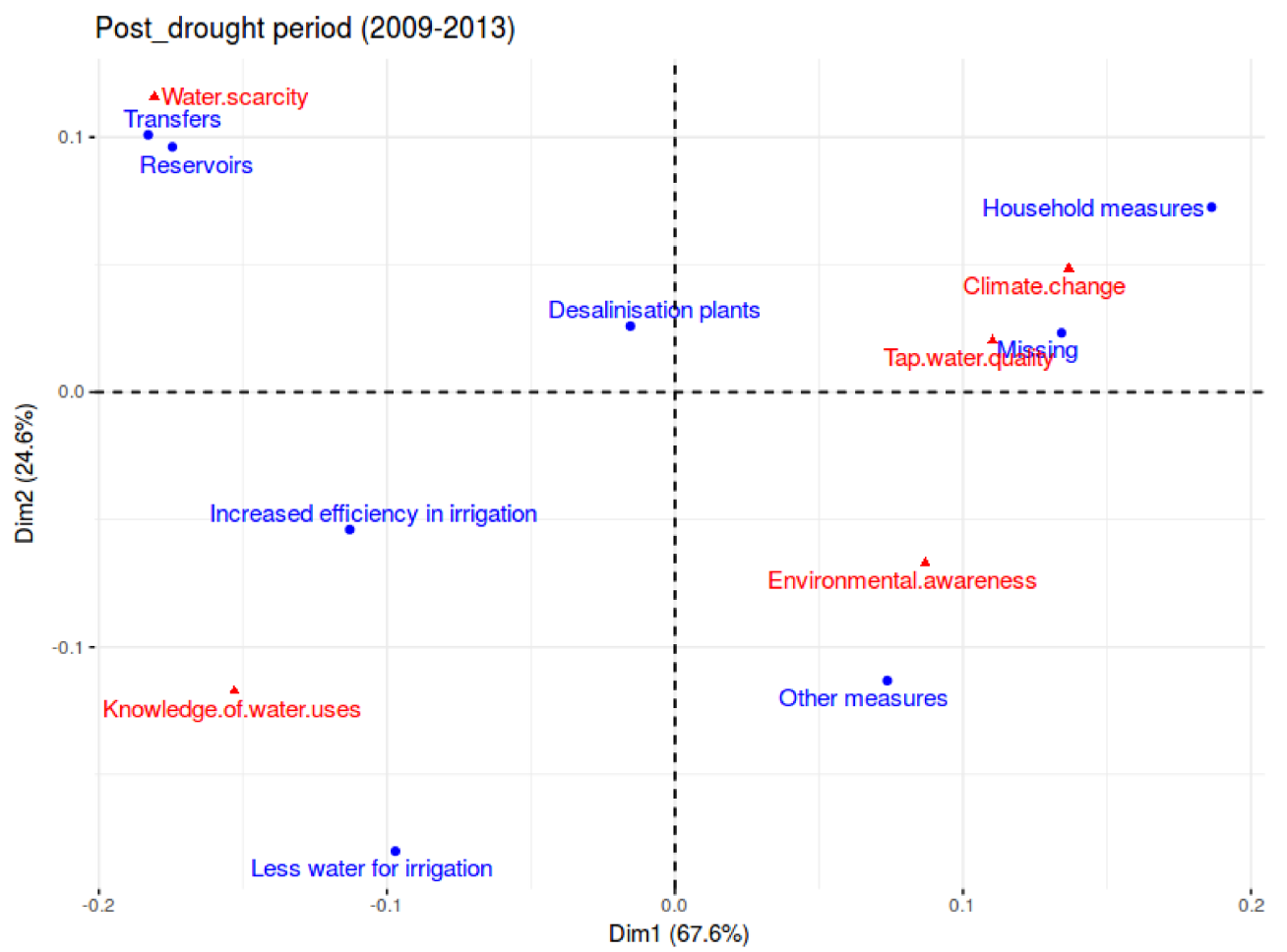

Figure 5. Correspondence analysis context variables and public preferences concerning water management policies in the post-drought period (2009-2013). Source: Authors' own after EBA 2004-2013 (IESA-CSIC).

In contrast with the preceding period, environmental awareness and an accurate knowledge of water distribution does not seem to have affected the levels of public support for the construction 
of desalinization plants. However, these respondents continued prioritizing the improvement of irrigation systems $(25.2 \%$ of well-informed respondents select this option, as do $28.1 \%$ of those who have an accurate knowledge of water allocation criteria), whereas those who expressed little environmental awareness believed that the responsibility for reducing water consumption fell on households ( $28 \%$ approximately). However, environmental information is more related to household measures $(23.56 \%)$ than knowledge regarding water allocation (15.9\%) (Dimension 1 Figure 5).

These results allow us to make some associations between different environmental concerns and preferences regarding water management policies during the different periods under consideration.

Concern over climate change is associated with a preference for saving water at the domestic level during all three periods, and with a lack of support for the construction of water reservoirs, even during the first period (a time when this policy was at its peak of popularity).

Support for the construction of water reservoirs decreased less among those who expressed concern over water scarcity-that is, the level of support was lower than that expressed by the rest of respondents before the drought ( $33.1 \%$ vs. $44.8 \%)$ but higher after the drought $(22.2 \%$ vs. $15.5 \%)$. Also, although public support for water transfers decreased overall, concern over water scarcity was generally paired with a higher degree of support for these infrastructures. Finally, those who expressed concern over water scarcity expressed more support for measures aimed at improving the efficiency of irrigation from the pre-drought period ( $16.4 \%$ vs. $10.5 \%)$.

During the period of drought, respondents with a higher level of environmental awareness and a more accurate knowledge of water distribution expressed more varied preferences concerning water management measures: the most popular measure was improving irrigation systems, followed by measures that aimed to reduce domestic uses and the construction of desalinization plants. However, those with a low level of environmental awareness and an inaccurate knowledge of water distribution tended to focus on measures aimed at reducing domestic consumption. After the drought, respondents with a higher level of environmental awareness and a more accurate knowledge of water distribution continued to express support for improving irrigation, whereas the rest of the respondents believed that the rationing of domestic usage was more important.

Finally, environmental awareness and an accurate knowledge of water distribution was dissociated from the degree of support for the construction of major hydraulic infrastructures, such as water reservoirs and transfers. Only during the period of drought did support for the construction of desalinization plants increase. Also, those who were aware that most water is used by the agricultural sector tended to express greater support for reducing the water available for irrigation, especially during the period of drought.

\section{Conclusions}

In Spain, public participation remains an exceptional occurrence. The EBA has thus become an exceptionally valuable tool for the collection of information regarding the perceptions, opinion, knowledge, attitudes, and behavior of Andalusians with regard to water. The scrapping of the project in 2013 is, therefore, bad news. The EBA also allows for the examination of public opinion on a scale which is consistent with that of hydrological planning and which adapts to the sociodemographic peculiarities of each basin.

A major finding of this work is the links between environmental and drought-related beliefs. Concern over (global) climate change and the degree of environmental awareness has risen steadily, regardless of the circumstances of each period. It should be taken into account that perceptions regarding such topics as climate change may take some time to mature [21]. While Carlton et al. [21], amongst others, have claimed that climate change-related beliefs do not change significantly as a result of a drought, others $[20,36]$ have stated that droughts impact on public opinions of climate change; more research is clearly needed in this regard. In contrast, our results suggest that drought has a direct impact on public concern for the quantity and quality of water available (regional/local), which 
confirms that drought has a direct bearing on water-related perceptions and that scale is a key variable in the evolution of environmental concerns.

Second, the results clearly demonstrate that drought has a significant impact on public preferences regarding water management policies, and that changes to these preferences during this period tended to consolidate during the post-drought period. As demonstrated by previous studies [19], drought triggers increasing concerns over water supply and regulatory solutions. During the period of drought, support for the construction of major hydraulic infrastructures (reservoirs and transfers) decreased, whereas that for measures which aimed to reduce domestic and agricultural consumption increased. However, given that $81.3 \%$ of water resources in Andalusia were used by the agricultural sector, it is remarkable that measures aimed at reducing the quantity of water available to agriculture garnered so little support. For this reason, it may be argued that, despite the considerable impact which drought has on public preferences concerning water management policies, the public's take on water management issues is highly conventional and the perception of resources is rooted in historically and geographically sensitive perspectives, in a clear example of "path dependency" [6]. These conventional perspectives stand in sharp contrast to the results obtained by other deliberative experiments [29,37], in which opinions were much more flexible and participants more open to gaining further knowledge.

Third, concerning the relationship that exists between general environmental concerns and public preferences regarding water management policies, it should be noted that concern over climate change is related to preferences for reducing domestic consumption and resistance to the construction of water reservoirs. The influence of environmental awareness and, especially, an accurate knowledge of water distribution, is also significant. Those respondents who expressed a greater degree of environmental awareness demonstrated greater support for the improvement of irrigation systems and, although to a lesser extent, the reduction of water available to the agricultural sector. However, it should also be pointed out that environmental awareness does not seem to play a role in shaping preferences concerning the construction of reservoirs and transfer infrastructures.

\section{Discussion}

The analysis of a topic such as water management models-which is so loaded with cultural nuances, conflicting economic interests, and inertia—cannot be undertaken unless the degree of social approval enjoyed by different policies is known, and the potential impact of water-related risks is analyzed. A sound knowledge of the population's motivations and perceptions assists the formulation of more efficient and sustainable policies while also detecting weak links in the chain of information, via which water-related information is conveyed. Also, this knowledge embodies the WFD's mandate to actively engage in public participation.

The findings presented here clearly illustrate that public attitudes towards water management measures are affected by conditions of drought, as well as by other contextual variables relating to environmental concerns and also to awareness at global, regional, and local levels. In general, we may suggest that the degree of information which the population has, as well as people's perception of risk, and their personal beliefs, all form a crucial context within which debates about water policies and drought mitigation are framed.

This context is also important when we consider management and strategic planning not only in relation to water management policies but also how to improve the information that is provided to the public. Thus, this context can help us to understand water-related social conflict in settings where water resources are exploited intensively and water-related risks are on the increase owing to climate change. It is in these territories, however, where the greatest resistance to changes in water management models is attested, and for this reason research programs such as that presented here are especially important. In order to achieve success, it is important to have sufficient data that cover prolonged time periods.

As other studies have demonstrated, to change conservation behavior, more is required than provision of information and education using mass media. Thus, it is also necessary to target specific 
segments within the community, identifying the larger discretionary end uses, prioritizing the areas where behavior can be changed, as well as identifying the barriers to change and developing the appropriate suite of interventions [15]. We must also take into consideration that public opinion on water issues is affected by flawed information on water policies and their implications. This limits the public's ability to adequately evaluate political action at different levels. The lack of information, or its distortion, undermines the quality of public debate, which also leads to the implementation of incorrect strategies [23].

Acknowledgments: This work was supported by the Plan Estatal de Fomento de la Investigación Científica y Técnica de Excelencia. Ministerio de Economía y Competitividad-FEDER. Convocatoria 2015 under Grant Evaluación de la vulnerabilidad socio-institucional a las sequías: propuesta metodológica, estudio de caso y elaboración de una Guía (EVALSOC). CSO2015-64026-P. We wish to thank the Instituto de Estudios Sociales de Andalucía del Consejo Superior de Investigaciones Científicas (IESA-CSIC) for the cesion of the Ecobarómetro de Andalucía's data, and José Luis Cañadas Reche for his advice in the statistical processing of the information.

Author Contributions: Pilar Paneque and Regina Lafuente conceived and designed the study; Regina Lafuente performed the analysis; Pilar Paneque, Regina Lafuente, and Jesús Vargas analyzed the data and results; all of the authors contributed to the paper writing.

Conflicts of Interest: The authors declare no conflict of interest.

\section{References}

1. Gleick, P.H. A look at twenty-fist century water resources development. Water Int. 2000, 25, 127-138. [CrossRef]

2. Biswas, A.K. Integrated water resources management: Is it working? Int. J. Water Resour. Dev. 2008, 24, 5-22. [CrossRef]

3. Pahl-Wostl, C. The implications of complexity for integrated water resources management. Environ. Model. Softw. 2007, 22, 561-569. [CrossRef]

4. Molle, F. Water, politics and river basin governance: Repoliticizing approaches to river basin management. Water Int. 2009, 34, 62-70. [CrossRef]

5. Parés, M. River basin management planning with participation in Europe: From contested hydro-politics to governance-beyond-the state. Eur. Plan. Stud. 2010, 19, 457-478. [CrossRef]

6. Shapiro, A.; Summers, R. The evolution of water management in Alberta, Canada: The influence of global management paradigms and path dependency. Int. J. Water Resour. Dev. 2015, 31, 732-749. [CrossRef]

7. Swyngedouw, E. Modernity and Hybridity: Regeneracionismo, the Production of nature and the Spanish Waterscape, 1890-1930. Ann. Assoc. Am. Geogr. 1999, 89, 443-465. [CrossRef]

8. Saurí, D.; Del Moral, L. Recent developments in Spanish water policy. Alternatives and conflicts at the end of the hydraulic age. Geoforum 2001, 32, 351-362. [CrossRef]

9. Del Moral, L.; van der Werff, P.; Bakker, K.; Handmer, J. Global trends and water policy in Spain. Water Int. 2003, 28, 358-366. [CrossRef]

10. Bukowski, J. Spanish water policy and the national hydrologic plan: An advocacy coalition approach to policy change. South Eur. Soc. Polit. 2007, 12, 39-57. [CrossRef]

11. Font, N.; Subirats, J. Water management in Spain: The role of policy entrepreneurs in shaping change. Ecol. Soc. 2010, 15, 25. [CrossRef]

12. López-Gunn, E. Agua para todos: A new regionalist hydraulic paradigm in Spain. Water Altern. 2009, 2, 370-394.

13. Paneque, P. Drought Management Strategies in Spain. Water 2015, 7, 6689-6701. [CrossRef]

14. Paneque, P.; Vargas, J. Drought, social agents and the construction of discourse in Andalusia. Environ. Hazards Hum. Pol. Dimens. 2015, 14, 224-235. [CrossRef]

15. Cary, J.W. Influencing attitudes and changing consumers' household water consumption behavior. Water Sci. Technol. Water Supply 2008, 8, 325-330. [CrossRef]

16. Dolnicar, S.; Schäfer, A.I. Desalinated versus recycled water: Public perceptions and profiles of the accepters. J. Environ. Manag. 2009, 90, 888-900. [CrossRef] [PubMed]

17. Gilbertson, M.; Hurlimann, A.; Dolnicar, S. Does water context influence behaviour and attitudes to water conservation? Australas. J. Environ. Manag. 2011, 18, 47-60. 
18. Graymore, M.L.M.; Wallis, A.M. Water savings or water efficiency? Water-use attitudes and behaviour in rural and regional areas. Int. J. Sustain. Dev. World Ecol. 2010, 17, 84-93. [CrossRef]

19. Bishop, B.H. Drought and environmental opinion. A study of attitudes toward water policy. Public Opin. Q. 2013, 77, 798-810. [CrossRef]

20. Evans, J.M.; Calabria, J.; Borisova, T.; Boellstorf, D.E.; Sochacka, N.; Smolen, M.D.; Mahler, R.L.; Risse, L.M. Effects of local drought condition on public opinions about water supply and future climate change. Clim. Chang. 2015, 132, 193-207. [CrossRef]

21. Carlton, J.S.; Mase, A.S.; Knutson, C.L.; Lemos, M.C.; Haigh, T.; Todey, D.P.; Prokopy, L.S. The effects of extreme drought on climate change beliefs, risk perceptions, and adaptation attitudes. Clim. Chang. 2016, 135, 211-226. [CrossRef]

22. Lazrus, H. 'Drought is a relative term': Drought Risk Perceptions and Water Management Preferences among Diverse Community Members in Oklahoma, USA. Hum. Ecol. 2016, 44, 595-605. [CrossRef]

23. Stoutenborough, J.W.; Vedlitz, A. Public Attitudes Toward Water Management and Drought in the United States. Water Resour. Manag. 2014, 28, 697-714. [CrossRef]

24. Stern, P.C. Toward a coherent theory on environmentally significant behavior. J. Soc. Issues 2000, 56, 407-424. [CrossRef]

25. Dunlap, R.E.; Van Liere, K.D.; Mertig, A.G.; Jones, R.E. Measuring endorsement of the New Ecological Paradigm: A revisited NEP. J. Soc. Issues 2000, 56, 425-442. [CrossRef]

26. Jiménez, M.; Lafuente, R. Defining and measuring environmental consciousness. Rev. Int. Soc. 2010, 68, 731-755. [CrossRef]

27. Lafuente, R.; Moyano, E. Andalucía y el Medio Ambiente 2000-2010: 10 Años del Ecobarómetro; Junta de Andalucía, Instituto de Estudios Sociales Avanzados (IESA/CSIC): Seville, Spain, 2011.

28. Valliant, R. Post-stratification and conditional variance estimation. J. Am. Stat. Assoc. 1993, 88, 89-96.

29. Ganuza, E.; Francés, F.; Lafuente, R.; Garrido, F. ¿Cambian sus preferencias los participantes en la deliberación? Rev. Esp. Investig. Soc. 2012, 139, 111-132. [CrossRef]

30. Junta de Andalucía. Memoria. Plan Hidrológico de la Demarcación Hidrográfica Guadalete Barbate 2015-2021; Junta de Andalucía: Seville, Spain, 2015.

31. Junta de Andalucía. Memoria. Plan Hidrológico de la Demarcación Hidrográfica Tinto-Odiel-Piedras 2015-2021; Junta de Andalucía: Seville, Spain, 2015.

32. Junta de Andalucía. Memoria. Plan Hidrológico de la Demarcación Hidrográfica de las Cuencas Mediterráneas Andaluzas 2015-2021; Junta de Andalucía: Seville, Spain, 2015.

33. MAGRAMA (Ministerio de Agricultura, Alimentación y Medio Ambiente). Memoria. Plan Hidrológico de la Demarcación Hidrográfica del Guadalquivir 2016-2021; MAGRAMA: Madrid, Spain, 2015.

34. Sampedro, D.; Del Moral, L. Tres décadas de política de aguas en Andalucía. Análisis de procesos y perspectiva territorial. Cuad. Geogr. 2014, 53, 36-67.

35. Del Moral, L.; Babiano, L.; Giansante, C. Actores, normas, prácticas y discursos en la asignación del agua en sequías. Aplicación al Guadalquivir. Rev. Real Acad. Cienc. Exactas Fís. Nat. 2000, 94, 287-301.

36. Brownlee, M.T.J.; Hallo, J.C.; Moore, D.D.; Powell, R.B.; Wright, B.A. Attitudes toward water conservation: The influence of site-specific factors and beliefs in climate change. Soc. Nat. Resour. 2014, 27, 964-982. [CrossRef]

37. Paneque, P.; Corral, S.; Guimaraes, A.; Del Moral, L.; Pedregal, B. Participative Multi-criteria Analysis for the Evaluation of Water Governance Alternatives. A case in the Costa del Sol (Málaga). Ecol. Econ. 2009, 68, 990-1005. [CrossRef]

(C) 2018 by the authors. Licensee MDPI, Basel, Switzerland. This article is an open access article distributed under the terms and conditions of the Creative Commons Attribution (CC BY) license (http:/ / creativecommons.org/licenses/by/4.0/). 